\title{
Consequences of International Financial Reporting Standards Adoption in Africa: Evidence From Foreign Direct Investment
}

\author{
Dr. Shuibin Gu, \\ Gigamon Joseph Prah, \\ Kofi K. Tenkorang,
}

School of Finance \& Economics, Jiangsu University, China

Doi:10.19044/esj.2019.v15n34p67～ＵRL:http://dx.doi.org/10.19044/esj.2019.v15n34p67

\begin{abstract}
International Financial Reporting Standards (IFRS) Adoption makes financial reporting transparent by enhancing the comparability and the quality of the financial information which reduces the transaction cost and attract foreign direct investment (FDI). This consequently facilitates the effective economic decisions of investors and other market participants. In light of this, many developing countries, in Africa, have resorted to the mandatory-IFRS adoption to enhance the inflow of foreign capital. The study, therefore, aims at finding out the effect of IFRS adoption on FDI inflows. We investigate whether the adoption of IFRS really enhances the inflow of foreign direct investment in developing countries. We use the Fixed Effect regression model, and the sample consisted of 45 (30 IFRS adopted and 15 IFRS non-adopted) African countries from the period of 2000 to 2017. The evidence from our study shows that the adoption of IFRS leads to increased FDI inflows. Most research on international financial reporting standard and foreign direct investment did not control the time period. By conducting further analysis using the difference-in-difference analysis to control the time period, our results highlighted that FDI inflows is higher after the adoption of IFRS. The increase in the value of FDI is influenced by the time period.
\end{abstract}

Keywords: FDI Inflows, IFRS Adoption, Africa, Developing Countries, Macro-Consequences

\subsection{Introduction}

FDI inflows are measures of direct investments by foreign investors into a host country which signify a controlling interests in firms in the host country. One of the most important economic policies of countries across the globe is to attract cross-border capital into their economies as a means of 
increasing their economic growth (Lungu, Caraiani, \& Dascălu, 2017; Zaidi \& Huerta, 2014). FDI has been identified as a strong key to international capital transfers over the last decades. It is considered a country's key element for economic integration and represent a key source of finance capital investment (Dellis, Sondermann, \& Vansteenkiste, 2017). It has been identified that investors prefer to invest in markets with high quality information which will enable them to assess their investments projects at a low cost (Gordon, Loeb, \& Zhu, 2012). In an attempt to improve the quality of financial reporting or information to enable easy flow of foreign investment, most countries have now adopted International Financial Reporting Standards (IFRS). IFRS Adoption is perceived to be the tool in achieving the transparency of financial information that will satisfy the information needs of foreign investors. IFRS adoption reduces the cost of acquiring information by investors and consequently increases the investors' willingness in investing across borders.

Since the beginning of the globalization of the adoption of harmonized accounting standards, there have been several empirical evidences on the impact of the harmonized accounting standards on earnings management (Capkun, Collins, \& Jeanjean, 2016; Mongrut \& Winkelried, 2019; Said, 2019; Taek, 2013), analysts forecast (Ernstberger, Krotter, \& Stadler, 2008; Jiao, Koning, Mertens, \& Roosenboom, 2012; Masoud, 2017), value relevance (Chebaane \& Othman, 2014; Jing \& Park, 2011; Müller, 2014), investment (Amiram, 2012; DeFond, Gao, Li, \& Xia, 2019; Gao \& Sidhu, 2018; Pagano, Röell, \& Zechner, 2002), information quality (Eng, Lin, \& Neiva De Figueiredo, 2019; Fayis Mahmoud Alshyoukh \& Manaf, 2019; Houqe, Easton, \& van Zijl, 2014). Prior studies have found positive capital market consequences after the adoption of IFRS (DeFond, Hu, Hung, \& Li, 2011; Li, 2010; Tan, Wang, \& Welker, 2011). Most of these studies, however, are the microeconomic impacts and on developed countries. Little attention has been paid to developing countries especially African countries.

Since the postulation and adoption of IFRS, there has been different views regarding the impacts on FDI. Some researchers are of the view that IFRS adoption leads to increase in FDI (Gordon et al., 2012; Lungu et al., 2017), whilst others are in disagreement with it (Adetula, Nwobu, \& Owalabi, 2014; Nnadi \& Soobaroyen, 2015). Some researchers are of the view that the adoption of IFRS only favors developed countries as against the developing countries. They argue that IFRS works best only in the countries that have strong institutions to help in the implementation and enforcement of the standards, and investor protection mechanisms (Kouki, 2018; Lasmin, 2012; Louis \& Urcan, 2014). Africa is characterized with weak institutions, yet most of the countries have adopted IFRS. As such this paper seeks to find out 
whether IFRS adoption by developing countries, in Africa, leads to increase or decrease in the inflows of FDI.

The objective is to find out whether after the adoption of IFRS, these African countries really benefit as a result of increased FDI. Based on the objective, we perform our analysis on 30 IFRS adopting countries from Africa, from the period of 2000 to 2017. We run our panel data analysis using Pooled OLS regression model. We find that IFRS adoption leads to increased FDI inflows. The study also considered the FDI inflows in countries that have not adopted IFRS. We find that countries that have adopted IFRS experience higher increased FDI inflows than countries that have not adopted IFRS.

Our study has the following contributions to the literature. Firstly, we distinguished our study from other studies by applying the difference-indifference analysis for comparability analysis of the IFRS adopted countries and the IFRS non-adopted countries. We analyze the effect of the time period on IFRS adoption on the FDI inflows.

Secondly, the study focus on developing countries as an evidence of study. Most researchers focused on developed countries which have strong institutions. DeFond et al. (2011) found that IFRS has a positive economic consequences on inflow of FDI in the case of countries with strong institutions. Our study adds to the literature by identifying macroeconomic consequences of IFRS adoption in developing countries, in Africa, with weak institutions. Thirdly, most researchers focused on capital markets upon the study of impact of IFRS. We emphasis on the ultimate macro purpose: international capital inflows.

Finally, the results of our study enhance our understanding on the macro economic consequences of IFRS adoption. The outcome goes to the far extent of aiding the countries and World Bank to assess the performance of IFRS adoption. The study could also be a motivation for other researchers to delve more into the economic consequences of IFRS adoption among developing countries.

The rest of our research paper is structured as follows: the next section presents a review of the literature with reference to the relevant studies that seek to address the relationship between IFRS adoption and FDI. After, the next section explains the theory underpinning the research study followed by the hypothesis. The methodology which includes the research design, variable definitions, and research models that were used for testing the hypothesis is explained in the next section. The last section presents the results, discussion and implications of the results. Conclusion is also given at the last section. 


\subsection{Literature Review}

\subsection{IFRS and its Consequences}

In this section of the research, we review the past literature on the consequences of IFRS adoption. There has been several debates on whether the adoption of IFRS is associated to the inflow of foreign capital (DeFond et al., 2011). The proponents of IFRS state that a higher financial reporting quality with improvement in the comparability of financial reports based on IFRS, lead to a greater cross-border flow of capital and a better integration of capital markets (Gladys Lee \& Fargher, 2000; McCreevy, 2005; Mita Aria, 2018). Investors do not have to spend much resources in interpreting the domestic GAAP of other countries. The adoption of IFRS reduces the crosscountry discrepancies in accounting rules and practices, thereby eliminating information barriers (Pagano et al., 2002). This reduces the cost involved in the ascertainment of information for decision making.

Most research on IFRS tends to concentrate on its effect on cost of equity capital (Edward Lee, Martin Walker, \& Christensen, 2008; Houqe, Monem, \& Zijl, 2016) and economic growth (Özcan, 2016). According to the Modernization theory (Gordon et al., 2012), FDI has a positive contribution to the economic growth of developing countries. This is because it is able to meet the demand for capital formation (de Mello, 1999; Firebaugh, 1992). Empirically, a number of studies show that FDI generates economic growth in the host country (Iwasaki \& Tokunaga, 2014; Pandya \& Sisombat, 2017; Pegkas, 2015).

Researchers have found that IFRS adoption increases cross-border capital inflows. DeFond et al. (2011) examined the changes in the foreign mutual investment fund in firms following the mandatory IFRS adoption in the European Union (EU) in 2005. They asserted that improvements in the comparability of financial information, which reduces the cost of information acquisition by investors, leads to cross-border investment. Using 14 IFRSmandating EU countries and 10 non-IFRS-mandating countries, for a period from 2003-2007, they found that improvement in comparability under mandatory IFRS adoption leads to increased investment by foreign mutual fund. This means that improved comparability of accounting information has the tendency of increasing the inflow of cross-border capital.

Yu and Wahid (2014) studied how ownership changes to changes in accounting distance (differences in accounting standards) between investees and investors' countries affect the investment allocation decisions. In identifying the depth of this effect, the authors stated that in the case where the differences in the accounting standards across the US and South Africa (SA) were disregarded, mutual funds from US would decrease their underweighting SA stocks by approximately $14 \%$. They also made additional analysis in the differences in the accounting standards based on IFRS adoption 
in the investors' country, where there are absolutely no changes in the accounting standards of the investee entity. They found out that mutual funds increase their investment weight in the investee firms. This indicates that differences in the accounting standards affect the demand of investors by means of imposing information-processing costs on those less familiar with the reporting standards.

Pagano et al. (2002) conducted a research analysis on foreign listed companies. On the contrary, they found no significant relationship between the cross-border investment and the adoption of the international accounting standard. The reason was attributed to the occurrence of prohibitive informational obstacles to the cross-border investments. (Amiram, 2012) argued that it is only investors from IFRS adopting countries who tend to increase their investments in other IFRS adopting countries. This means that increment in cross-border investment is as a result of familiarity of the investor with IFRS, rather than the IFRS improving the reporting quality of accounting information to foreign investors.

Florou and Pope (2012) examined the effect of IFRS adoption on institutional ownership by studying the investment allocation decisions of all types of institutional investors around the world from the period of 2003-2006. They found that institutional ownership and the number of institutional investors increased for mandatory IFRS adopters. The positive change in the institutional ownership was attributed to strong investors whose investment decisions were based on the quality of financial statements information.

\subsection{IFRS and FDI}

A number of empirical studies have shown that IFRS adoption enhances FDI in adopting countries, and this affirmation corresponds to the announcements and policies of several international organizations such as World Bank (WB), and International Monetary Fund (IMF). Contrastingly, the findings of (Nnadi \& Soobaroyen, 2015), using 34 countries over a period of 20 years, differ significantly as they conclude that the comparability effect of full IFRS adoption leads to a negative impact on the net FDI of African countries. Their studies drew two implications. First, considering African countries, foreign investors are concerned mostly about the costs of doing business in an IFRS-regulated environment. Second, rule of law, legal system, and the level of corruption, instead of the adoption of IFRS enhance the inflow of FDI.

In their studies, (Lungu et al., 2017) examined the effect of IFRS adoption on FDI for 26 emerging countries from the period of 1996 to 2014. In their examination, they found that countries that have adopted IFRS are likely to have a high benefit of FDI inflows as compared with countries that have not adopted IFRS. The result is evidenced in (Gordon et al., 2012) which 
implies that higher accounting standards (IFRS) promotes the inflow of FDI. Chen, Ding, and Xu (2014) used the gravity model for 20 OECD countries from 2000 to 2005. They found that IFRS promotes FDI inflows as it reduces information processing costs for foreign investors. Similarly, (MárquezRamos, 2008) examined the effect of IFRS adoption on FDI using the gravity framework. The result provided evidence that there is positive relationship that exist between IFRS adoption and FDI. This was the first empirical evidence for the analysis of the effect of IFRS adoption on FDI.

Pricope (2017) investigated the impact of IFRS adoption on FDI in poor countries, using the propensity score matching method for 38 poor countries between 2008 and 2014. The results indicated that IFRS adoption has a positive impact on FDI inflows in poor countries. Yousefi Nejad, Ahmad, Md Salleh, and Abdul Rahim (2018) analyzed the effect of IFRS adoption on the flow of FDI using 10 ASEAN countries from 2001 to 2016. Their result supported the argument that IFRS adoption is positively associated with the flow of FDI.

Considering the above discussion, there is evidence that IFRS adoption has an association with the flow of FDI. However, most of these assertions are true on developed countries. The studies show that improved comparability and transparency of IFRS, coupled with investors' familiarity with IFRS is important factor to the inflow FDI. It also appears that most of the investigations into the impact of IFRS on FDI did not consider the event that occurred at the same time with the IFRS adoption. That is to say, the pre and post-event that might have influence on the impact of IFRS adoption on FDI were not controlled by most works and this could cause their findings to be incorrect. Our research, therefore, shall use the DID analysis to resolve this gap.

\subsection{Theoretical Framework and Hypothesis}

Investment across-borders is one of the risky decisions that investors undertake which requires the investor to have adequate knowledge about the host country environment. As far as FDI is concerned, Investors incur lots of costs prior to starting up or investing in a business. One of these costs is transaction cost. Transaction cost is defined by Williamson as the effort, time, and the various expenditure that individuals or organizations put in place in order to acquire valuable information for contract negotiation, bargaining and enforcement (Williamson, 1985). This cost could be coordination cost and motivation cost, information cost and strategic cost. The investor is able to acquire knowledge on costs of doing business, stocks of infrastructure, market size, and foreign investment policies only through the public information. However, this relevant information is costly to be obtained and that makes information costs a problem to foreign investors. Egwuatu (2013) stated that 
the cost involved in raising funds largely depends on the quality of information presented to potential and existing investors, as well as the basis of accounting policies applied. Lack of or inadequate knowledge by investors on the basis of accounting applied in the financial statements implies higher information processing costs and higher risks. However, the cost of raising capital reduces in the case of adoption of IFRS.

IFRS adoption eases the complexity of financial statements, reducing information processing cost and the higher risks involved in investment. Inconveniences created as a result of barriers in financial information is reduced since the IFRS adoption makes the financial information comparable. The reduction in transaction costs inspire investors to increase their investments in firms in those countries, hence increases the flow of foreign capital.

Considering the transaction cost theory, we hypothesized that:

$\mathrm{H}_{1}$ : Foreign Direct Investment inflows increases after the adoption of IFRS.

\subsection{Methodology}

\subsection{Research Design}

We conducted the research using a panel data research design to analyze the effect of IFRS adoption on FDI inflows in Africa. The study used the Fixed Effect (FE) regression model to estimate the effect of IFRS adoption on FDI. We used E-Views (10 ${ }^{\text {th }}$ edition) statistical tool to analyze the data. Other economic variables that influence the inflows of FDI were taken into consideration. First, we tested for the effect of IFRS adoption on FDI inflows for the countries that have adopted IFRS. We further examined the IFRS adoption influence on FDI for both IFRS-adopting and IFRS non-adopting countries using a difference-in-difference analysis.

\subsection{Model}

To test the impact of IFRS adoption on FDI inflows among African countries, we apply the following regression equation:

$\ln F D I_{i, t}=\beta_{0}+\beta_{1} I F R S(D U M M Y)_{i, t}+\beta_{2} \ln G D P P C i_{, t}+\beta_{3} \ln I N F L A T_{i, t}+$ $\beta_{4} \operatorname{lnOPENN}{ }_{i, t}+\beta_{5} \mathrm{ROL}_{i, t}+\beta_{6} \mathrm{VOACC}_{i, t}+\beta_{7} \mathrm{CORR}_{i, t}+\beta_{8} \mathrm{POL}_{i, t}+$ $\beta_{9} P E R I O D_{i, t}+\varepsilon_{i, t}$

\subsection{Definition of Variables and sources}

The natural logarithm is taken for FDI, hence lnFDI. The study uses a dummy variable of 1 for Post-adoption, and 0 for Pre-adoption. This study also uses controlling variables such as gross domestic product per capital, inflation, Openness to trade, voice and accountability, perception of corruption, political stability, and rule of law. GDPPC, Openness to trade, 
voice and accountability, political stability and rule of law are expected to have positive coefficient to FDI inflows. Inflation and corruption perception are expected to have negative coefficient. The table 1 below shows a summary of the variables of study, definition and measurement, and their sources.

Table 1: Variable definition

\begin{tabular}{|c|c|c|}
\hline Variables & Measurements & Source of Data \\
\hline $\operatorname{lnFDI}$ & $\begin{array}{l}\text { Natural logarithm of net foreign direct } \\
\text { investment inflow data measured in current US } \\
\text { Dollars }\end{array}$ & $\begin{array}{l}\text { World Development } \\
\text { Indicators (WDI) by World } \\
\text { Bank }\end{array}$ \\
\hline IFRS(DUMMY) & $\begin{array}{l}\text { The Dummy variable is assigned } 1 \text { after the } \\
\text { country has adopted IFRS, and } 0 \text { before adoption }\end{array}$ & $\begin{array}{l}\text { IFRS Foundation database } \\
\text { (www.ifrs.org) }\end{array}$ \\
\hline LnGDPPC & $\begin{array}{l}\text { Natural logarithm of gross domestic product per } \\
\text { Capita in current US dollars }\end{array}$ & $\begin{array}{l}\text { World Development } \\
\text { Indicators (WDI) by World } \\
\text { Bank }\end{array}$ \\
\hline LnINFLAT & $\begin{array}{l}\text { Natural logarithm of inflation, GDP deflator } \\
\text { (annual \%) }\end{array}$ & $\begin{array}{l}\text { World Development } \\
\text { Indicators (WDI) by World } \\
\text { Bank }\end{array}$ \\
\hline lnOPENN & $\begin{array}{l}\text { Openness to trade measures the sum of the exports } \\
\text { and imports of goods and services measured as a } \\
\text { share of gross domestic product. The natural } \\
\text { logarithm is used. }\end{array}$ & $\begin{array}{l}\text { World Development } \\
\text { Indicators (WDI) by World } \\
\text { Bank }\end{array}$ \\
\hline VOACC & $\begin{array}{l}\text { Reflects perceptions of the extent to which a } \\
\text { country's citizens are able to participate in selecting } \\
\text { their government as well as freedom of expression, } \\
\text { freedom of association, and a free media }\end{array}$ & $\begin{array}{l}\text { Worldwide Government } \\
\text { Indicators (WGI-2018) }\end{array}$ \\
\hline ROL & $\begin{array}{l}\text { Measures the perception of agents' confidence on } \\
\text { rules and regulations of the country }\end{array}$ & $\begin{array}{l}\text { Worldwide Government } \\
\text { Indicators (WGI-2018) }\end{array}$ \\
\hline CORR & $\begin{array}{l}\text { Reflects perceptions of the extent to which public } \\
\text { power is exercised for private gain, including both } \\
\text { petty and grand forms of corruption, as well as } \\
\text { "capture" of the state by elites and private interests }\end{array}$ & $\begin{array}{l}\text { Worldwide Government } \\
\text { Indicators (WGI-2018) }\end{array}$ \\
\hline POL & $\begin{array}{l}\text { Political Stability and Absence of Violence or } \\
\text { Terrorism measures perceptions of the likelihood } \\
\text { of political instability and/or politically-motivated } \\
\text { violence, including terrorism }\end{array}$ & $\begin{array}{l}\text { Worldwide Government } \\
\text { Indicators (WGI-2018) }\end{array}$ \\
\hline PERIOD & $\begin{array}{l}\text { We assigned a dummy variable of } 1 \text { for period } \\
\text { from } 2005 \text {, and } 0 \text { for periods prior to } 2005\end{array}$ & \\
\hline
\end{tabular}




\subsection{Sample Selection}

The population of the study consisted of all the 54 African countries. We examined the IFRS status of all the 54 African countries from the data published by various institutions such as IFRS Foundation database (www.ifrs.org), Deloitte \& Touche (www.iasplus.com), and PWC (www.pwc.com). We later sampled the countries based on their IFRS status and came out with 45 countries as the sample size for study. The 9 countries were removed due to lack of information about their IFRS status and unavailability of data. Our final 45 countries (30 IFRS adopted and 15 IFRS non-adopted) were classified based on the IFRS status, namely; Full Adoption, Partial Adoption, and adoption by modification; and the rest as Non Adoption. This is shown in the appendix 1 and appendix 2. The table reveals that out of the 45 African countries, 12 have fully adopted IFRS, 10 have partially adopted, 8 adoption by modification, and 15 IFRS non-adopting countries. In considering the IFRS status of these 45 countries, we found from IFRS foundation database that countries like Cote D'Ivoire, Guinea, Guinea Bissau, Togo, Chad, Equatorial Guinea, Republic of Congo, Comoros, and Central Republic of Africa, which are part of the Organization for the Harmonization of Corporate Law in Africa (OHADA) began to use IFRS standards in their consolidated financial statements early this year, 2019. Since our study covers a period from 2000 to 2017, we excluded them from countries that have adopted IFRS and listed them as IFRS non-adopting countries.

The study uses a secondary source of data. The data was collected from the World Bank -World Development Indicators (WDI) and World Government Indicators (WGI). The IFRS status of each country is obtained from the IFRS Foundation database (https://www.ifrs.org/use-around-the-world/use-of-ifrsstandards-by-jurisdiction/). 
Table 2: Summary of sample selection

\begin{tabular}{|c|c|c|c|}
\hline $\mathrm{S} / \mathrm{N}$ & $\begin{array}{c}\text { Number of } \\
\text { sampled countries }\end{array}$ & $\begin{array}{l}\text { Basis of } \\
\text { Selection }\end{array}$ & Reasons \\
\hline 1 & 54 & $\begin{array}{c}\text { Developing } \\
\text { countries in } \\
\text { Africa }\end{array}$ & $\begin{array}{l}\text { Total number of developing } \\
\text { countries in Africa }\end{array}$ \\
\hline 2 & 50 & IFRS Status & $\begin{array}{l}\text { Countries which have their } \\
\text { IFRS status presented in the } \\
\text { database of institutions such } \\
\text { as IFRS foundation, PWC, } \\
\text { Deloitte \& Touche, and the } \\
\text { periodicals. We ruled out } 4 \\
\text { countries (Djibouti, } \\
\text { Somalia, South Sudan and } \\
\text { Libya) because there was no } \\
\text { much information whether } \\
\text { they have adopted IFRS or } \\
\text { not }\end{array}$ \\
\hline 3 & 47 & $\begin{array}{l}\text { Period of } \\
\text { adoption }\end{array}$ & $\begin{array}{l}\text { We did not consider the } \\
\text { countries that adopted IFRS } \\
\text { before } 2001 \text {. So countries } \\
\text { like Kenya, Zimbabwe and } \\
\text { Uganda were removed. }\end{array}$ \\
\hline 4 & 45 & Data & $\begin{array}{l}\text { Eritrea was removed due to } \\
\text { limitations in data } \\
\text { availability. We removed } \\
\text { Tunisia also in order to have } \\
\text { a balanced set of } 30 \\
\text { countries (15 IFRS- } \\
\text { adopting countries and } 15 \\
\text { non-IFRS-adopting } \\
\text { countries) for the further } \\
\text { analysis. }\end{array}$ \\
\hline
\end{tabular}

\subsection{Results}

\subsection{Variable Descriptions}

This section provides the descriptive statistics of the data. For the purpose of examining the relationship that exist between IFRS adoption and foreign direct investment inflows, we selected a sample of 45 African countries; 30 IFRS-adopted countries and 15 IFRS non-adopted countries. The table 3 presents the descriptive statistics for IFRS adopters and IFRS nonadopters using a period from 2000 to 2017.

We use the univariate analysis by applying the t-test to compare the means of the empirical variables for IFRS adopters and IFRS non-adopters. From the results in table 3, we find that FDI inflows and GDPPC are higher in countries that have adopted IFRS than IFRS non-adopters. Countries that have 
adopted IFRS also have their economies more open to trade than countries that have not adopted IFRS.

Table 3: Descriptive Statistics of Empirical Variables

\begin{tabular}{|c|c|c|c|c|c|c|}
\hline \multirow[b]{2}{*}{ Variable } & \multicolumn{2}{|c|}{ Adopters } & \multicolumn{2}{|c|}{ Non-Adopters } & \multirow{2}{*}{$\begin{array}{c}\text { T- test } \\
\mathrm{t}- \\
\text { value }\end{array}$} & \multirow[b]{2}{*}{$\begin{array}{c}\text { Sign. } \\
\text { (two } \\
\text { tailed) }\end{array}$} \\
\hline & Mean & SD & Mean & $\mathrm{SD}$ & & \\
\hline LNFDI & 19.645 & 1.705 & 18.106 & 2.413 & -10.190 & 0.000 \\
\hline LNGDPPC & 7.091 & 1.160 & 6.762 & 1.029 & -3.946 & 0.000 \\
\hline LNINFLAT & 1.820 & 1.174 & 1.635 & 1.204 & -1.920 & 0.055 \\
\hline LNOPENN & 3.993 & 0.461 & 3.906 & 0.505 & -2.467 & 0.014 \\
\hline ROL & -0.443 & 0.578 & -1.004 & 0.522 & -13.465 & 0.000 \\
\hline VOACC & -0.400 & 0.662 & -0.829 & 0.695 & -8.558 & 0.000 \\
\hline CORR & -0.427 & 0.562 & -0.869 & 0.590 & -10.379 & 0.000 \\
\hline POL & -0.306 & 0.834 & -0.804 & 0.911 & -7.759 & 0.000 \\
\hline
\end{tabular}

All variable definitions appear in Table 1. All figures are approximated to 3 decimal figures.

\subsection{Results of Empirical Analysis}

This section reports the results on the impact of IFRS adoption on the inflows of FDI. We first test for the regression equation model that is appropriate for our analysis. This is shown in table 4. The Hausman test is carried out to decide between random effect and fixed effect model. According to the test, the p-value is less than $5 \%$ so we reject the null hypothesis. We, therefore, conclude fixed effect model to be appropriate for the regression.

Table 4: Diagnostic test

Test Summary

Cross-section random
Chi-sq. statistics 70.165759
Chi-sq. $d f$

9
Probability

0.0000

Table 5 shows the results of the empirical model for testing the hypothesis. We test the effect of IFRS adoption on FDI. The objective of this analysis is based on the debate on the relevance of the adoption of IFRS. Thus we intend to find whether FDI inflows really increases after the adoption of IFRS. Therefore, we assume in our hypothesis that the adoption of IFRS has a positive impact on the inflows of FDI. IFRS adoption is represented by a dummy variable IFRS (dummy). From the results in table 5, IFRS (dummy) adoption has a positive and significant impact on the net FDI inflows at 0.05. The results show that the decision by developing countries to adopt IFRS has an impact of $24.1 \%$ on the inflows of FDI. The results support the choice for 
adoption of IFRS by developing countries. The time effect variable (PERIOD) is also positive and significant.

Considering the discussion above, we declare acceptance of the hypothesis. We, therefore, report that the adoption of IFRS by developing countries, in Africa, has a positive impact on the inflows of FDI.

Table 5: Impacts of IFRS Adoption on FDI using FE

\begin{tabular}{ccccc} 
Variables & Coeff. & Std. Error & t-statistic & Prob. \\
\hline $\begin{array}{c}\text { IFRS } \\
\text { (dummy) }\end{array}$ & 0.241 & 0.118 & 2.050 & 0.041 \\
LNGDPPC & 1.157 & 0.158 & 7.312 & 0.000 \\
LNINFLAT & 0.032 & 0.042 & 0.775 & 0.439 \\
LNOPENN & 1.309 & 0.183 & 7.146 & 0.000 \\
ROL & 0.184 & 0.295 & 0.626 & 0.531 \\
VOACC & -0.309 & 0.260 & -1.189 & 0.235 \\
CORR & 0.258 & 0.252 & 1.024 & 0.306 \\
POL & -0.070 & 0.129 & -0.544 & 0.587 \\
PERIOD & 0.300 & 0.145 & 2.076 & 0.039 \\
Intercept & 5.905 & 1.420 & 4.159 & 0.000 \\
\hline
\end{tabular}

Note: All variable definition appear in Table 1 and significance at the 5\% and $1 \%$ respectively. All figures are approximated in 3 decimal figures.

\subsection{Further Analysis}

We conducted further test to check the time period effects on IFRS adoption and the impacts on FDI inflows. We considered the influence of the time period on the inflows of FDI as a result of IFRS adoption. The test was carried out based on the difference in lnFDI for IFRS adopting and IFRS nonadopting countries, before and after the year 2005. The difference-indifference (DID) removed any biases in the post-intervention period or the biases from comparisons over time. We used a sample of 30 countries which consisted of the 15 IFRS non-adopted countries and 15 IFRS adopted countries. A dummy variable of IFRS (Adopt) was assigned 1 if the country has adopted IFRS, and 0 otherwise. We introduced an interaction term in our analysis. The regression equation with the interaction term is presented in the equation below:

$\operatorname{lnFDI}_{i, t}=\beta_{0}+\beta_{1}$ PERIOD $+\beta_{2}$ IFRS $(\text { ADOPT })_{i, t}+\beta_{3}$ IFRS $(A D O P T * P E R I O D)+\beta_{4} \ln G D P P C i_{, t}$ $+\beta_{5} \operatorname{lnINFLAT}{ }_{i, t}+\beta_{6} \ln O P E N N_{i, t}+\beta_{7} \operatorname{ROL}_{i, t}+\beta_{8} V_{O A C C_{i, t}}+\beta_{9} \mathrm{CORR}_{i, t}+$ $\beta_{10} P O L_{i, t}$

Where, IFRS $(A D O P T) * P E R I O D$ is the interaction term. 
In this analysis, we use a difference-in-difference (DID) estimator to control for the two groups (IFRS adopted and IFRS non-adopted countries) at different time periods. The DID is estimated using the Robust Least Square model. The aim is to examine the effect of the time period and IFRS adoption on net FDI. We, therefore, regress period, IFRS (ADOPT), and IFRS (Adopt* Period) against net FDI. The results are shown in table 6.

Table 6: Interaction Analysis

\begin{tabular}{ccccc}
\hline Variable & Coeff. & Std. Error & Z-stat & Prob. \\
\hline PERIOD & 0.105 & 0.229 & 0.461 & 0.645 \\
IFRS(adopt) & 0.667 & 0.242 & 20.757 & 0.006 \\
$\begin{array}{c}\text { IFRS(adopt } \\
* \text { period) }\end{array}$ & 0.886 & 0.300 & 2.953 & 0.003 \\
LNGDPPC & 0.806 & 0.088 & 9.169 & 0.000 \\
LNINFLAT & 0.188 & 0.072 & 2.590 & 0.010 \\
LNOPENN & 0.629 & 0.182 & 3.460 & 0.001 \\
ROL & 1.574 & 0.342 & 4.601 & 0.000 \\
VOACC & 0.025 & 0.180 & 0.139 & 0.889 \\
CORR & -1.177 & 0.266 & -4.430 & 0.000 \\
POL & -1.244 & 0.150 & -8.267 & 0.000 \\
Intercept & 9.775 & 0.856 & 11.421 & 0.000 \\
\hline
\end{tabular}

Note: All variable definition appear in Table 1 and significance at the $5 \%$ and $1 \%$ respectively. All figures are approximated in 3 decimal figures.

From the table 6, IFRS (Adopt) is positive and significant at 0.01, which indicates that countries that have adopted IFRS experience a more successive increase in FDI inflows than countries that have not adopted IFRS. Furthermore, our interaction between IFRS (Adopt) and Period is positive and statistically significant at 0.01 . This means that the effect of adoption of IFRS on net FDI inflows depends on the time period. The relationship between IFRS adoption and net FDI inflows changes as a result of the time period.

\section{Discussion of Results}

We sought to find whether IFRS adoption by African countries increases the FDI inflows after the adoption. The results reveal that IFRS adoption leads to increase in FDI inflows. The results also show that countries that adopt IFRS experience a higher increase in FDI than countries that have not adopted IFRS. This creates an awareness that investors prefer to invest in countries under IFRS environment. Our evidence is consistent with the 
argument that IFRS adoption, as a measure to increase FDI, is valid choice for developing countries.

This result consequently, has a great implication to policy makers and other interested groups. Our findings provide evidence that the form of financial reporting standards used by entities in a countries determines the level of foreign direct investment that is possible of flowing into that particular country. There is an awareness that investors currently consider the financial reporting standard of the firms they seek interest in investing. Policymakers are therefore to ensure the consideration of IFRS adoption as part of their macroeconomic decisions.

The results highlight the need for Africa to embark on measures that will induce economic development. This is because a percentage increase in GDPPC leads to more than $100 \%$ increase in FDI inflows. The economic policy makers can use measures like education, transparency score, tax cuts and tax rebates, infrastructural spending, discovery of natural resources in enhancing the continual development of the economy.

The results also highlight that a percentage increase in openness to trade leads to more than $100 \%$ increase in the inflows of FDI. Policymakers are therefore to take notice and ensure effective and efficient opening up of their economies for trading activities that enhance FDI inflows.

\section{Conclusion}

This paper examines the impact of IFRS adoption on FDI inflows among African countries using pooled OLS model. The study covers 45 African countries from the period 2000 to 2017. We find support for the argument that IFRS adoption has a positive relationship with the inflow of FDI. This means that IFRS adoption enhances the inflow of FDI. Also, with the comparison of 15 IFRS adopting countries and 15 IFRS non-adopting countries, there is a clear indication that investors like to invest more in IFRS adopting countries than IFRS non-adopting countries.

This research offers an opportunity to advance the concerns of international accounting harmonization and its effects on developing countries. Policymakers of developing countries are, therefore, to take notice in considering the adoption of IFRS as part of their macroeconomic decisions. Africa is characterized by political instability. In our results, we found that political instability has an adverse effect on the inflow of FDI. The government of the various countries in Africa should take notice of the adverse effect of political instability and take measures to ensure peace and political stability. As it is in most empirical studies, our study has a limitation. There is no complete theoretical model predicting the inflows of FDI. However, previous empirical studies have examined some determinants of FDI inflows in 
countries. Our study could not make use of all the determinants of foreign direct investment as control variables.

Notwithstanding this, future research could be done on the macroeconomic impact of IFRS on other developing countries by other interested researchers, with more advanced statistical model and more variables that influence FDI inflows.

\section{References:}

1. Adetula, D. T., Nwobu, O., \& Owalabi, F. (2014). International financial reporting standards and foreign direct investment in Nigeria. Journal of Commerce, Business and Management, 3(3), 446-449.

2. Amiram, D. (2012). Financial Information Globalization and Foreign Investment Decisions (Vol. 11).

3. Capkun, V., Collins, D., \& Jeanjean, T. (2016). The effect of IAS/IFRS adoption on earnings management (smoothing): A closer look at competing explanations. Journal of Accounting and Public Policy, 35(4), 352-394. doi:https://doi.org/10.1016/j.jaccpubpol.2016.04.002

4. Chebaane, S., \& Othman, H. B. (2014). The Impact of IFRS Adoption on Value Relevance of Earnings and Book Value of Equity: The Case of Emerging Markets in African and Asian Regions. Procedia - Social and Behavioral Sciences, 145, 70-80. doi:https://doi.org/10.1016/j.sbspro.2014.06.012

5. Chen, C. J. P., Ding, Y., \& Xu, B. (2014). Convergence of accounting standards and foreign direct investment. The International Journal of Accounting, 49(1), 53-86. doi:https://doi.org/10.1016/j.intacc.2014.01.007

6. de Mello, J. L. R. (1999). Foreign direct investment-led growth: evidence from time series and panel data. Oxford Economic Papers, 51(1), 133-151. doi:10.1093/oep/51.1.133

7. DeFond, M., Gao, X., Li, O. Z., \& Xia, L. (2019). IFRS adoption in China and foreign institutional investments. China Journal of Accounting Research, 12(1), 1-32. doi:https://doi.org/10.1016/j.cjar.2018.07.006

8. DeFond, M., Hu, X., Hung, M., \& Li, S. (2011). The impact of mandatory IFRS adoption on foreign mutual fund ownership: The role of comparability. Journal of Accounting and Economics \$V 51(3), 240-258.

9. Dellis, K., Sondermann, D., \& Vansteenkiste, I. (Eds.). (2017). Determinants of FDI inflows in Advanced Economics: Does the quality of economic structures matter? : European Central Bank. 
10. Edward Lee, Martin Walker, \& Christensen, H. B. (2008). Mandating IFRS: Its Impact on the Cost of Equity Capital in Europe Retrieved from London:

11. Egwuatu, P. (2013). Adoption of IFRS will attract foreign direct investment-ICAN. Vanguard media limited. Retrieved from https://www.vanguardngr.com/2013/11/adoption-ifrs-will-attractforeign-direct-investment-ican/

12. Eng, L. L., Lin, J., \& Neiva De Figueiredo, J. (2019). International Financial Reporting Standards adoption and information quality: Evidence from Brazil. Journal of International Financial Management \& Accounting, 30(1), 5-29. doi:10.1111/jifm. 12092

13. Ernstberger, J., Krotter, S., \& Stadler, C. (2008). Analysts' Forecast Accuracy in Germany: The Effect of Different Accounting Principles and Changes of Accounting Principles. Business Research, 1(1), 2653. doi:10.1007/bf03342701

14. Fayis Mahmoud Alshyoukh, \& Manaf, K. B. A. (2019). The effects of Mandatory IFRS Adoption on Accounting Information Quality: Empirical Evidence from Jordan. Social Science and Humanities Journal, 3(7).

15. Firebaugh, G. (1992). Grwoth Effects of Foreign and Domestic Investment. American Journal of Sociology, 98(1), 105-130.

16. Florou, A., \& Pope, P. F. (2012). Mandatory IFRS Adoption and Institutional Investment Decisions. The Accounting Review, 87(6), 1993-2025.

17. Gao, R., \& Sidhu, B. K. (2018). The Impact of Mandatory International Financial Reporting Standards Adoption on Investment Efficiency: Standards, Enforcement, and Reporting Incentives. Abacus, 54(3), 277-318. doi:10.1111/abac.12127

18. Gladys Lee, \& Fargher, N. (2000). Did the adoption of IFRS encourage cross-border investment? Retrieved from www.academia.edu/33474932/Did_the_Adoption_of_IFRS_Encoura ge_Cross-Border_Investment

19. Gordon, L. A., Loeb, M. P., \& Zhu, W. (2012). The impact of IFRS adoption on foreign direct investment. Journal of Accounting and Public Policy, 31(4), 374-398. doi:https://doi.org/10.1016/j.jaccpubpol.2012.06.001

20. Houqe, M. N., Easton, S., \& van Zijl, T. (2014). Does mandatory IFRS adoption improve information quality in low investor protection countries? Journal of International Accounting, Auditing and Taxation, 23(2), 87-97. doi:https://doi.org/10.1016/j.intaccaudtax.2014.06.002 
21. Houqe, M. N., Monem, R. M., \& Zijl, T. v. (2016). The economic consequences of IFRS adoption: Evidence from New Zealand. Journal of International Accounting, Auditing and Taxation, 27, 40-48. doi:https://doi.org/10.1016/j.intaccaudtax.2016.10.001

22. Iwasaki, I., \& Tokunaga, M. (2014). Macroeconomic Impacts of FDI in Transition Economies: A Meta-Analysis. World Development, 61, 53-69. doi:https://doi.org/10.1016/j.worlddev.2014.03.022

23. Jiao, T., Koning, M., Mertens, G., \& Roosenboom, P. (2012). Mandatory IFRS adoption and its impact on analysts' forecasts. International Review of Financial Analysis, 21, 56-63. doi:https://doi.org/10.1016/j.irfa.2011.05.006

24. Jing, L., \& Park, S.-K. (2011). The Value Relevance Effects of IFRS Adoption: The Case of The People's Republic of China. Korea International Accounting Review, 38, 215-218.

25. Kouki, A. (2018). Mandatory IFRS adoption, investor protection and earnings management. International Journal of Accounting \&amp; Information Management, 26(1), 187-204. doi:10.1108/IJAIM-072017-0091

26. Lasmin, D. (2012). The unwanted effects of international financial reporting standards (IFRS) adoption on international trade and investments in developing countries. Journal of Economics and Economic Education Research, 13(1), 1-14.

27. Li, S. (2010). Does Mandatory Adoption of International Financial Reporting Standards in the European Union Reduce the Cost of Equity Capital? The Accounting Review, 85(2), 607-636. doi:10.2308/accr.2010.85.2.607

28. Louis, H., \& Urcan, O. (2014). The Effect of IFRS on Cross-Border Acquisitions.

29. Lungu, C. I., Caraiani, C., \& Dascălu, C. (2017). The Impact of IFRS Adoption on Foreign Direct Investments: Insights for Emerging Countries. Accounting in Europe, 14(3), 331-357. doi:10.1080/17449480.2017.1374546

30. Márquez-Ramos, L. (2008). The Effect of IFRS Adoption on Trade and Foreign Direct Investments.

31. Masoud, N. (2017). The effects of mandatory IFRS adoption on financial analysts' forecast: Evidence from Jordan. Cogent Business \& Management, 4(1), 1290331. doi:10.1080/23311975.2017.1290331

32. McCreevy, C. (2005). IFRS-No Pain, no Gain? [Press release]

33. Mita Aria, F. (2018). The adoption of IFRS, comparability of financial statements and foreign investors' ownership. Asian Review of Accounting, 26(3), 391-411. doi:10.1108/ARA-04-2017-0064 
34. Mongrut, S., \& Winkelried, D. (2019). Unintended effects of IFRS adoption on earnings management: The case of Latin America. Emerging Markets Review, 38, 377-388. doi:https://doi.org/10.1016/j.ememar.2018.11.004

35. Müller, V.-O. (2014). The Impact of IFRS Adoption on the Quality of Consolidated Financial Reporting. Procedia - Social and Behavioral Sciences, 109 , 976-982. doi:https://doi.org/10.1016/j.sbspro.2013.12.574

36. Nnadi, M., \& Soobaroyen, T. (2015). International financial reporting standards and foreign direct investment: The case of Africa. Advances in Accounting, 31(2), 228-238. doi:https://doi.org/10.1016/j.adiac.2015.09.007

37. Özcan, D. A. (2016). Asssessing the Effects of IFRS Adoption on Economic Growth: A Cross Country Study. International Journal of Social Sciences, 2(2), 65-80.

38. Pagano, M., Röell, A. A., \& Zechner, J. (2002). The Geography of Equity Listing: Why Do Companies List Abroad? Journal of Finance, 57(6), 2651-2694.

39. Pandya, V., \& Sisombat, S. (2017). Impacts of Foreign Direct Investment on Economic Growth: Empirical Evidence from Australian Economy. Journal of Economics and Finance, 9(5). doi: https://doi.org/10.5539/ijef.v9n5p121

40. Pegkas, P. (2015). The impact of FDI on economic growth in Eurozone countries. The Journal of Economic Asymmetries, 12(2), 124-132. doi:https://doi.org/10.1016/j.jeca.2015.05.001

41. Pricope, C. F. (2017). The implications of IFRS adoption on foreing direct investment in poor countries. The Audit Financiar Journal, 15(146).

42. Said, K. (2019). The Impact of IFRS Adoption on Earnings Manangement-Results from Canada. Journal of Economics and Business, 540-554.

43. Taek, O. H. (2013). The Effect of the Mandatory K-IFRS Adoption on Earnings Management-The Evidence from Korea. International Journal of Digital Content Technology and its Applications (JDCTA), $7(11)$.

44. Tan, H., Wang, S., \& Welker, M. (2011). Analyst Following and Forecast Accuracy After Mandated IFRS Adoptions. Journal of Accounting Research, 49(5), 1307-1357. doi:10.1111/j.1475679X.2011.00422.x

45. Williamson, O. E. (1985). The economic institutions of capitalism : firms, markets, relational contracting. New York :: Free Press ;. 
46. Yousefi Nejad, M., Ahmad, A., Md Salleh, M. F., \& Abdul Rahim, R. (2018). IFRS Adoption and Foreign Direct Investment: An Application of the LSDVC Estimator.

47. Yu, G., \& Wahid, A. S. (2014). Accounting Standards and International Portfolio Holdings. The Accounting Review, 89(5), 1895-1930. doi:10.2308/accr-50801

48. Zaidi, S., \& Huerta, E. (2014). IFRS Adoption and Enforcement as Antecedents of Economic Growth. International Journal of Accounting and Financial Reporting, 4(1).

Appendix 1: List of countries according to IFRS Status

\begin{tabular}{|c|c|c|}
\hline COUNTRY & $\begin{array}{c}\text { YEAR OF IFRS } \\
\text { ADOPTION }\end{array}$ & IFRS STATUS \\
\hline Botswana & 2007 & Full Adoption \\
\hline Egypt & 2006 & Modified \\
\hline Ghana & 2007 & Full Adoption \\
\hline Malawi & 2001 & Full Adoption \\
\hline Mauritius & 2001 & Full Adoption \\
\hline Nigeria & 2012 & Full Adoption \\
\hline Rwanda & 2008 & Full Adoption \\
\hline Sierra Leone & 2006 & Full Adoption \\
\hline South Africa & 2005 & Full Adoption \\
\hline Tanzania & 2004 & Full Adoption \\
\hline Zambia & 2005 & Full Adoption \\
\hline Angola & 2015 & Partial Adoption \\
\hline Algeria & 2009 & Modified \\
\hline Burundi & & Not Adopted \\
\hline Ethiopia & 2009 & Modified \\
\hline Gabon & 2009 & Modified \\
\hline Burkina Faso & 2012 & Modified \\
\hline Gambia & 2007 & Partial Adoption \\
\hline Liberia & 2012 & Partial \\
\hline Madagascar & 2005 & Partial Adoption \\
\hline Morocco & 2004 & Partial Adoption \\
\hline Cameroun & 2009 & Partial \\
\hline Benin & 2008 & Partial \\
\hline Lesotho & 2001 & Partial \\
\hline Mali & 2010 & \\
\hline Mozambique & 2006 & \\
\hline & & \\
\hline & & \\
\hline
\end{tabular}


Appendix 2: List of countries according to IFRS Status continues

\begin{tabular}{|c|c|c|}
\hline Seychelles & 2009 & Modified \\
\hline Swaziland & 2009 & Full Adoption \\
\hline Cote D'Ivoire & & Not Adopted \\
\hline Guinea & & Not Adopted \\
\hline Guinea Bissau & & Not Adopted \\
\hline Mauritania & & Not Adopted \\
\hline Cape Verde & & Not Adopted \\
\hline Comoros & & Not Adopted \\
\hline Togo & & Not Adopted \\
\hline Sudan & 2012 & Partial \\
\hline Senegal & 2005 & Full Adoption \\
\hline Namibia & & Not Adopted \\
\hline Central Republic of Africa & & Not Adopted \\
\hline Equatorial Guinea & & Not Adopted \\
\hline Sao Tome \& Principe & & Not Adopted \\
\hline Congo Republic & & Partial \\
\hline Democratic Republic of & & Not Adopted \\
Congo & 2014 & Not Adopted \\
\hline Chad & & \\
\hline Niger & & \\
\hline
\end{tabular}

Source: www.ifrs.org, www.ifac.org, www.pwc.com 